\title{
The Nitrogen Industry and our Food Supply.*
}

By Dr. R. E. Slade.

$\mathrm{F}^{\mathrm{O}}$ OR many centuries nitrogen was used as a fertiliser in the form of farmyard manure, and certain rotations of crops, which kept up the nitrogen in the soil, had been popular; but it was not until 1840, when Liebig first pointed out the true function of nitrogen, potash, and phosphorus, that fertilising became an art based on science. Liebig's work became widely known in a very short time. A little later Lawes and Gilbert started their experiments at Rothamsted, which definitely proved the part taken by nitrogen in agriculture.

From 1840 the use of nitrogen in the form of Chile nitrate steadily increased, and about 1880 sulphate of ammonia became available from by-product coke ovens, and by 1903 the world consumption of these two fertilisers had increased to $1,975,000$ tons, equivalent to 351,000 tons of nitrogen.

In 1905 calcium cyanamide was manufactured on a commercial scale for use as a fertiliser, and in the same year the arc process for combining the oxygen and nitrogen of the air to form nitric acid was launched unsuccessfully in Canada. Two years later the arc process was established in Norway and calcium nitrate was put on the market as a fertiliser. Thus Crookes's dream of the commercial production of nitrogenous fertilisers from the nitrogen of the air was realised in less than ten years. But it was the Haber-Bosch process for the fixation of nitrogen which was to supersede all others and make it possible for us to produce all the nitrogen fertilisers we require now and as far in the future as we can see. In 1906-9 Prof. Haber investigated the chemical equilibrium between nitrogen, hydrogen, and ammonia when heated under a pressure over a catalyst. Then Dr. Bosch of the Badisch Analin u. Soda Fabrik successfully manufactured ammonia on a large scale by this process in 1913 to 1914.

The fixation of nitrogen in the form of ammonia is so much cheaper than by any other process that this process has very largely replaced the cyanamide and arc processes, and it has shaken the Chile nitrate industry to its foundations-so that the Chilean Government and the nitrate manufacturers have to revise their methods and their processes.

The production of nitrogen in various forms is

* From an evening discourse delivered at the meeting of the British Association at Bristol on Sept. 9.

No. 3180, VoL. 126] shown in Fig. 1. The quantities are expressed in tons of nitrogen contained in the products. It will be noticed that the nitrogen industry had already achieved considerable importance in 1898 , but it was not until 1921 that the synthetic nitrogen production became greater than the Chilean nitrate production.

\section{Nitrogen Fertilisers.}

The world's consumption in 1928 of nitrogen in the form of ammonium sulphate from synthetic

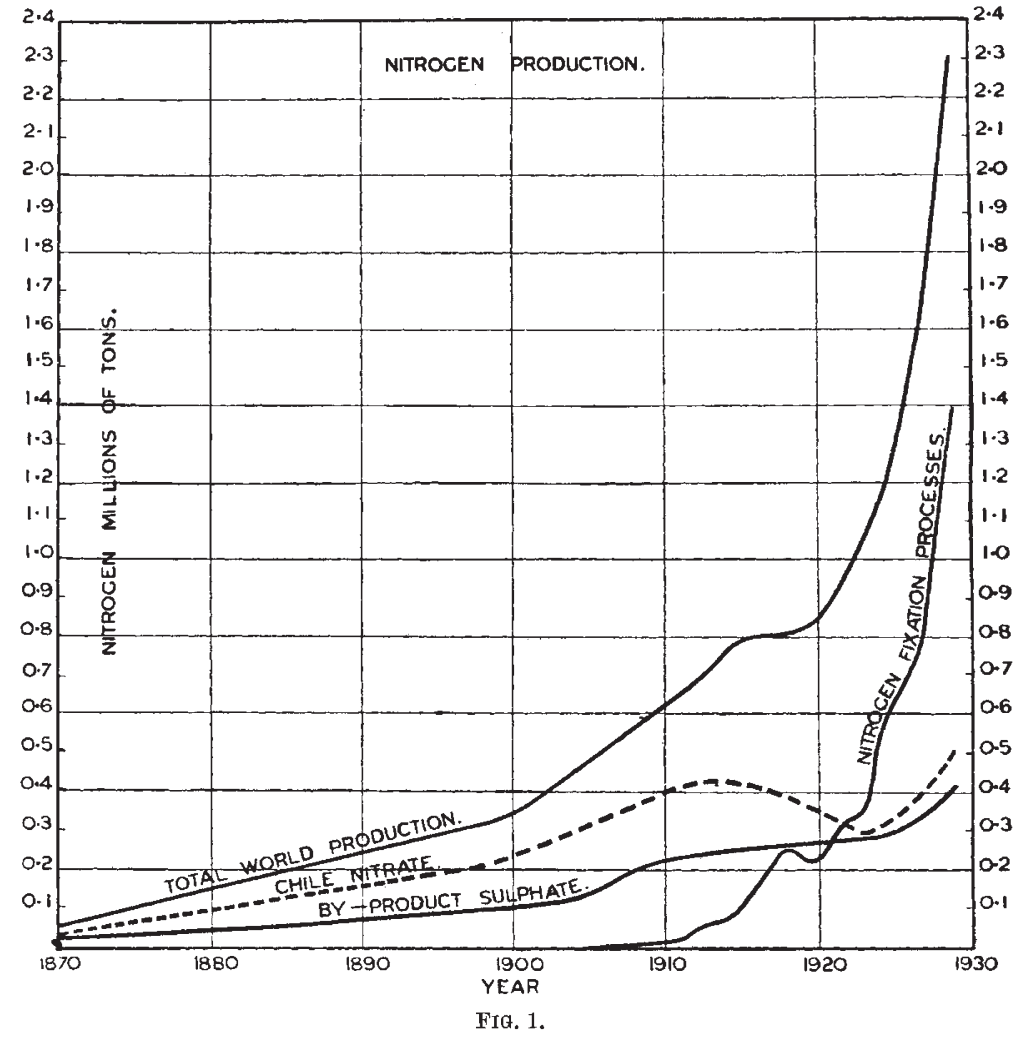

ammonia and by-product coke ovens, cyanamide, nitrate of lime, nitro-chalk, and ammonia liquor was $1,442,000$ tons and in the form of Chile nitrate 401,000 tons, making a total of $1,843,000$ tons, of which 185,000 tons are used in industry and $1,658,000$ tons are consumed as fertilisers. If fixed nitrogen is worth $£ 50$ a ton-which is about its price in sulphate of ammonia to-day-then the value of the nitrogen used in fertilising was $£ 83,000,000$.

Now, in an acre of typical English arable soil we have in the top nine inches a quantity of humus containing about $2500 \mathrm{lb}$. of nitrogen, and at certain times of the year changes take place in the soil making some of this nitrogen into nitrates, in which form it is available for absorption by the plant. The result of this is that in the spring about one per cent of the nitrogen in the humus is present 
in the form of nitrate ; thus we have present about $25 \mathrm{lb}$. of nitrogen available for the plant. As this available nitrogen is used up by the plant it is partly replaced by more nitrate being formed from the humus, but during the time of greatest growth there is a considerable depletion of available nitrogen in the soil. Owing to the continuous breaking down of the humus, the nitrogen absorbed by the plant is often more than $25 \mathrm{lb}$., besides what is washed away by rain. The supply of available nitrogen may be increased by the addition of nitrates or ammonium salts-for the latter are rapidly oxidised to nitrates in the soil.

If we spread one hundredweight of sulphate of ammonia over an acre of ground, this adds $23 \mathrm{lb}$. of nitrogen to this area, or if we consider the top nine inches of the soil over this area of an acre, we add $1 \mathrm{lb}$. of nitrogen to each $120,000 \mathrm{lb}$. of soil. This is such a small amount that we might be doubtful whether it would be sufficient to make any appreciable difference to plants grown on this area. But we have seen that this quantity is of the same order as the quantity of available nitrogen already in the soil.

We will now inquire into the magnitude of the increased yields of crops which can be obtained by the use of nitrogen fertilisers. The figures given in Table I. are average increased yields of various crops obtained on good soil for the addition of each lb. of nitrogen in a fertiliser. They are the averages over many years and many different soils, so that they are the increased yields that may be expected for the addition of each lb. of nitrogen--if there is not a deficiency of potash or phosphoric acid in the soil.

TABLE I.

\begin{tabular}{|c|c|c|c|}
\hline Crop. & $\begin{array}{l}\text { Increase for } \\
1 \mathrm{lb} . \\
\text { Nitrogen. } \\
\text { (lb.) }\end{array}$ & $\begin{array}{l}\text { Nitrogen in } \\
\text { Crop. } \\
\text { (Per Cent.) }\end{array}$ & $\begin{array}{l}\text { Nitrogen } \\
\text { Efficiency. } \\
\text { (Per Cent.) }\end{array}$ \\
\hline Wheat (grain) & $11 \cdot 4$ & 1.8 & $20 \cdot 4$ \\
\hline Barley (grain) & $14 \cdot 2$ & $1 \cdot 3$ & $18 \cdot 5$ \\
\hline Oats (grain) & $12 \cdot 4$ & $1 \cdot 6$ & $19 \cdot 7$ \\
\hline Potatoes (tubers) & $94 \cdot 0$ & $0 \cdot 3$ & $28 \cdot 2$ \\
\hline Swedes (roots) & $94 \cdot 0$ & $0 \cdot 2$ & $18 \cdot 8$ \\
\hline Mangolds (roots) & $150 \cdot 0$ & 0.2 & $30 \cdot 0$ \\
\hline Hay. & $42 \cdot 3$ & $1 \cdot 45$ & $61 \cdot 5$ \\
\hline
\end{tabular}

The nitrogen efficiency of the fertilisers in the last column is the percentage of the nitrogen in the fertilisers which appears in whole or part of the crop described in the first column.

In Table II. the increased yields are recalculated so as to show the increased crop obtained from one hundredweight of sulphate of ammonia in common units.

\begin{tabular}{|c|c|c|c|c|c|c|}
\hline \multicolumn{7}{|l|}{ Cro } \\
\hline Wheat & • & $\theta^{\circ}$ & $4 \cdot$ & ushels & 5 or 2.41 & cwt. \\
\hline Barley & . & - & $6 \cdot 5$ & , & or 3.02 & פ" \\
\hline Oats & . & • & . $7 \cdot 0$ & ," & or 2.62 & , \\
\hline Potatoes & . & • & . & . & $20 \cdot 0$ & ", \\
\hline Swedes & & . & . & 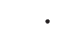 & $20 \cdot 0$ & , \\
\hline Mangolds & & . & . & . & $32 \cdot 0$ & $"$ \\
\hline Hay & - & . & . & . & $9 \cdot 0$ & ,, \\
\hline
\end{tabular}

If we feed grass to a cow giving two gallons of milk a day, we find that $1 \mathrm{lb}$. of nitrogen causes sufficient extra grass to grow to keep the cow alive one day and to give two gallons of milk. Since two gallons of milk contain $0.8 \mathrm{lb}$. of proteins or $0.128 \mathrm{lb}$. of nitrogen, we have 12.8 per cent of the nitrogen of the fertiliser appearing in the milk, or the efficiency with which the fertiliser is used via grass to make milk is $12 \cdot 8$ per cent.

The efficiency of meat production is lower, one pound of nitrogen fertiliser only producing $0.05 \mathrm{lb}$. of nitrogen in beef, or an efficiency of 5 per cent on the fertiliser.

Summing up these nitrogen efficiencies we have:

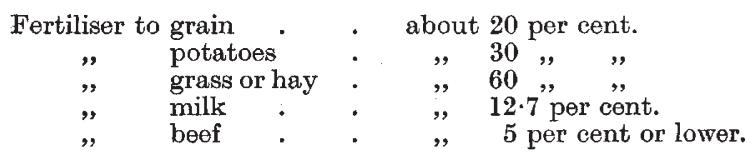

It is not surprising that grass shows a higher efficiency than other crops, because the roots cover the ground more completely. I think that the efficiencies on the whole are very high; compare the energy efficiency of a high-class locomotive on the railways, which is not more than 8.per cent.

\section{Food Production.}

The food of a man in Great Britain is approximately :

\begin{tabular}{|c|c|c|c|c|c|c|c|}
\hline Meat, fish & . & & & & $14 \cdot 5$ & per & cent. \\
\hline Cereals & . & & & & $18 \cdot 5$ & , & ," \\
\hline Milk, chees & e, etc. & & • & & $24 \cdot 5$ &, & , \\
\hline Potatoes ar & ad roots & & - & - & $25 \cdot 8$ & , & 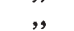 \\
\hline Sugar, fruit & t, etc. . & • & . & • & $15 \cdot 5$ & , & , \\
\hline
\end{tabular}

-and the nitrogen efficiency in growing these foods from fertilisers is probably about 17 per cent.

The amount of protein consumed per head is $86.5 \mathrm{gm}$. per day; this contains $14 \mathrm{gm}$. of nitrogen, so that if this food were grown by using fertilisers at an efficiency of 17 per cent we should require to use $82 \mathrm{gm}$. of nitrogen in fertilisers to produce the food for one person for one day ; or the fertiliser required to feed one person for a year must contain $365 \times 80 \mathrm{gm}$., or $29 \mathrm{kgm}$. of nitrogen. One ton of nitrogen in the form of sulphate of ammonia or nitrate of soda will therefore produce enough food for 34 people for one year.

Since the total amount of nitrogen consumed in fertilisers during 1928 was $1,658,000$ tons, the amount of extra food produced from this fertiliser would contain enough nitrogen in the form of proteins to support $56,000,000$ people ; and there would be sufficient carbohydrates and fat associated with this protein to form a complete diet.

Sir Daniel Hall has shown that 2-21 acres of land are required under cultivation to feed one person. Let us compare this with $1 / 34$ tons of fixed nitrogen. If we assume that the total capital required to build a nitrogen factory is $£ 70$ - 100 per ton year of nitrogen, inclusive of everything, then for a maximum of $£ 3$ invested we can support one person. It would be impossible to bring $2-2 \frac{1}{2}$ acres of land under cultivation at so low a capital cost. I do not think that land can usually be settled and cultivated at a less capital cost than $£ 10$ per acre, including roads and railways, houses, and agricultural machinery, so that to bring two and a half

No. 3180 , VoL. 126] 
acres under cultivation would need $£ 25$ capital as compared with $£ 3$ necessary to produce the fertiliser to produce the same amount of food. I would particularly like to direct attention to this calculation in some countries where governments are always ready to consider and finance schemes to build railways and roads to open up new country or to build irrigation schemes, although the capital to be invested for a given amount of food-producing capacity is often enormous.

\section{Stability of the Nitrogen Fixation Industry.}

In fixing one ton of nitrogen and making it into fertilisers we use for all purposes about five and a half tons of coal, so that to provide the fertiliser to feed one person for a year we require $3 \frac{1}{4}$ cwt. of coal. The population of the world (excluding China and Turkey) is now about 1940 millions, and 56 millions or 2.8 per cent are now being fed with food grown by nitrogen fertilisers. Of the nitrogen fertilisers consumed in the year 1928, about $1,000,000$ tons of nitrogen was produced by synthesis, needing 5.5 million tons of coal. This quantity of coal is almost negligible when compared with 1500 million tons mined every year. The rest of the nitrogen was produced by by-product coke ovens or as nitrate of soda from Chile.

The population of the world increased by 10 millions each year from 1913 to 1928 . If we had to feed this increase of population by increased nitrogen fertilisation, we should have to build each year a works which would fix 300,000 tons of nitrogen per year and would cost upwards of $£ 30,000,000$. In order to run the works we should require 1.6 million tons of coal per year. If we built a works of this size every year for a hundred years, we should then be consuming 160 million tons of coal a year for nitrogen fixation, or only ten per cent of the coal which is being used in the world to-day. At least two-thirds of the coal consumed in the fixation of nitrogen is used for power production, so we could reduce the coal required to one-third the value mentioned if other sources of power were available. There are still large areas of the world suitable for cultivation. It is therefore improbable that all the food requirements for the growing population of the world will have to be supplied exclusively from nitrogenous fertilisers for some time to come.

\section{Distribution of Nitrogen Fertiliser.}

Let us now investigate the use which the world makes of the nitrogenous fertilisers available at the present time. I have already mentioned that of the
$1,843,000$ tons of nitrogen consumed in 1928, $1,658,000$ tons or 90 per cent was used in agriculture.

In Table III. are shown the quantities of nitrogen consumed in the different countries during the year 1928 .

How much atmospheric nitrogen is combined by electric discharges ? How much by bacteria? How

NITROCEN CYCLE. UNITED KINCDOM.

(ALL FICURES REFER TO TONS OF NITROCEN IN 1928)

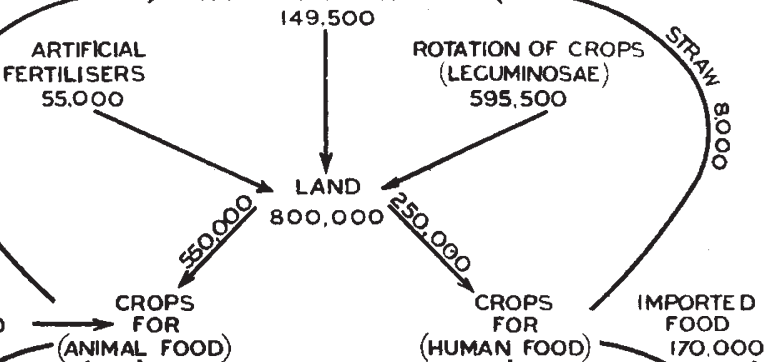

(ANIMAL FOOD)

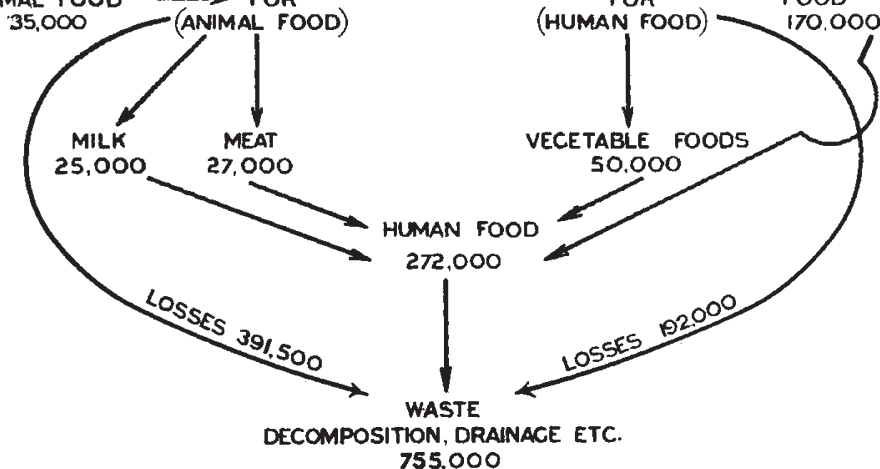

FIG. 2.

much by our synthetic ammonia processes? How much humus changes to give nitrate? How much

TABLE III.

\begin{tabular}{|c|c|c|c|}
\hline & \multicolumn{2}{|c|}{ Nitrogen Consumed. } \\
\hline & & Metric Tons, 1928. & Lb./Acre Arable. \\
\hline Germany & ( & 615,200 & $22 \cdot 3$ \\
\hline France. & & 166,900 & $6 \cdot 7$ \\
\hline Belgium & & 63,600 & $45 \cdot 9$ \\
\hline Czechoslovakia. & . & 33,800 & $5 \cdot 0$ \\
\hline Denmark . & : & 29,100 & $9 \cdot 8$ \\
\hline Holland & . & 73,400 & $70 \cdot 6$ \\
\hline Italy . & . & 68,300 & $4 \cdot 7$ \\
\hline Poland. & & 54,600 & $2 \cdot 7$ \\
\hline Spain . & & 67,300 & $3 \cdot 8$ \\
\hline Great Britain & & 61,600 & $10 \cdot 4$ \\
\hline Total (Europe & . & $1,134,800$ & \\
\hline U.S.A. . & . & 383,600 & $2 \cdot 4$ \\
\hline Japan & & 113,300 & $16 \cdot 8$ \\
\hline Egypt . & & 35,900 & $9 \cdot 2$ \\
\hline Other countries. & & 175,600 & . \\
\hline Total (World) & . & $1,843,200$ & . \\
\hline
\end{tabular}

nitrate is washed away and how much goes into

No. 3180, VoL. 126] 
the crop? What happens to that going into the crop and how much of it forms humus? What happens to the dissolved nitrogen going down the rivers into the sea? How much comes back to land in the form of fish? Again, how much nitrogen is liberated again from combination? Is there a dynamic equilibrium in this nitrogen cycle-or are we drifting in one direction? Are we gaining nitrogen in the air or are we losing it ?

We cannot get answers to these questions. There is no doubt that, in the past, nitrogen was stored up in coal and in Chile nitrate, and this is being liberated now, but we do not know whether nitrogen is being stored up anywhere at the present time. In the diagram, Fig. 2, I have made an estimate of the principal movements in the nitrogen cycle of Great Britain for the year 1928.

The vegetable food-stuffs consumed by man are estimated to contain 50,000 tons of nitrogen. If these are grown with a nitrogen efficiency of 20 per cent, then 250,000 tons of nitrogen is required in the soil. Of this nitrogen it is assumed that 50,000 tons go into vegetable foods, 8000 tons into straw which forms farmyard manure, and the rest, 192,000 tons, are washed out of the ground by rain water and lost to the rivers and seas. It will be noticed that I have assumed that the wastage of nitrogen derived from humus is the same as the wastage of nitrogen from artificial fertilisers. I have no direct evidence for this-I have no evidence at all; but I cannot think of a more reasonable assumption. I have taken no account of the vegetable and animal life on the moors and mountains except so far as it provides human food. Probably I have neglected some other important factors, but I make no apology for offering this first attempt at a nitrogen flow sheet for Great Britain.

We are now getting much better statistics of agricultural production than formerly, and I believe that consideration of these statistics with other statistics now available has opened up new fields of study in agricultural economics. I have calculated the average amount of nitrogen obtained from an acre of crops in different countries. The figures in Table IV. are for the year 1928. They were obtained by calculating the weight of nitrogen in each crop for each country and then adding up the total amounts of nitrogen for each country. This weight of nitrogen is then divided by the area on which the crops grew and we get the weight of nitrogen in the crop in lb. per acre average over the whole country. By crop we mean the portion of the crop taken away for consumption by man or animals : for example, of wheat the grain, of potatoes the tubers, etc. The rest of the crop usually goes back to the land and is considered as part of the agricultural system of the country.

Since some crops give a larger yield of nitrogen, in the useful part of the crop, than others, the figures in the table are to some extent affected by the different crops and different proportions of each crop grown in the country. But so far as I can see, the effect of the different crops grown is of only minor importance, and as the production of proteins is the farmers' business, we are not far wrong in considering the first column as an index of the agricultural efficiency of that part of the country under crops. In the second column is

TABLE IV.

\begin{tabular}{|c|c|c|c|}
\hline Year 1928. & \multicolumn{3}{|c|}{ Lb. per A.cre. } \\
\hline Country. & $\begin{array}{l}\text { Total } \\
\text { Nitrogen in } \\
\text { Crops. }\end{array}$ & $\begin{array}{l}\text { Nitrogen in } \\
\text { Crops from } \\
\text { Artificial } \\
\text { Fertilisers. }\end{array}$ & $\begin{array}{l}\text { Nitrogen in } \\
\text { Crops from } \\
\text { Humus. }\end{array}$ \\
\hline Denmark & $52 \cdot 0$ & $2 \cdot 4$ & $49 \cdot 6$ \\
\hline Holland & $49 \cdot 0$ & $17 \cdot 6$ & $31 \cdot 4$ \\
\hline Belgium & $47 \cdot 2$ & $11 \cdot 5$ & $35 \cdot 7$ \\
\hline Great Britain & $40 \cdot 2$ & $2 \cdot 6$ & $37 \cdot 6$ \\
\hline Japan & $34 \cdot 2$ & $4 \cdot 2$ & $30 \cdot 0$ \\
\hline Germany. & $32 \cdot 5$ & $5 \cdot 6$ & $26 \cdot 9$ \\
\hline Egypt & $31 \cdot 6$ & $2 \cdot 3$ & $29 \cdot 3$ \\
\hline France & $23 \cdot 5$ & $1 \cdot 7$ & $21 \cdot 8$ \\
\hline Canada & $21 \cdot 8$ & $0 \cdot 1$ & $21 \cdot 7$ \\
\hline U.S.A. & $20 \cdot 8$ & $0 \cdot 6$ & $20 \cdot 2$ \\
\hline Italy. & $20 \cdot 5$ & $1 \cdot 2$ & $19 \cdot 3$ \\
\hline
\end{tabular}

given that part of the nitrogen in the crop which has been supplied by artificial fertilisers. It is assumed that on an average 25 per cent of the nitrogen supplied to the land as fertiliser is found in the useful portion of the crop. The third column is the difference between the other two columns and is the weight of nitrogen in the crop which has been supplied by the land. In countries with a good system of farming and a good rotation of crops this quantity is high. We see that the system of agriculture in Denmark produces more than twice as much as that in Canada, U.S.A., and Italy, and that in Great Britain we are a little better than Belgium and considerably better than Holland in our agricultural system, apart from the use of artificial nitrogen fertilisers. But since Holland uses seven times and Belgium four times as much nitrogen fertiliser per acre, these two countries obtain greater crops than those obtained in Great Britain, as is shown in the first column.

In Holland one-third of the crops appear to be grown from nitrogen fertilisers. There seems to be no climatic or other physical reason why fertilisers should not be used to a greater extent in Great Britain. If we used as much per acre as in Holland, we should consume 420,000 tons of nitrogen per year ; if as much as in Belgium, 272,000 tons; and if as much as in Germany, 132,000 tons. The reason that we do not use more fertilisers does not appear to be economic. The use of sulphate of ammonia yields 100-300 per cent on the money invested within a year. Consider the special case of the fertilisation of wheat. For some years the price of wheat and of sulphate of ammonia has been practically equal. Since 1 cwt. of sulphate of ammonia gives an increased yield of wheat of $2 \cdot 4$ cwt., even after paying for phosphatic and potash fertilisers, one hundred per cent will be earned on money spent on nitrogen.

Development of the nitrogen fixation industry has lowered the price of nitrogen fertilisers, so that we can expect the needs of the increasing population of the world to be met first by more intensive cultivation of land close to the markets for food rather than by extension of the cultivated area.

$$
\text { No. } 3180 \text {, VoL. 126] }
$$

